Article

\title{
Effect of Different Fertilization Practices on Soil Microbial Community in a Wheat-Maize Rotation System
}

\author{
Yunlong Zhang ${ }^{1,2}$, Tengteng $\mathrm{Li}^{2}$, Honghui $\mathrm{Wu}^{3}$, Shuikuan Bei ${ }^{2}$, Junling Zhang ${ }^{2}$ and \\ Xiaolin Li ${ }^{2, *}$ \\ 1 National Hulunber Grassland Ecosystem Observation and Research Station, Institute of Agricultural \\ Resources and Regional Planning, Chinese Academy of Agricultural Sciences, Beijing 100081, China \\ 2 College of Resources and Environmental Sciences, China Agricultural University, Beijing 100193, China \\ 3 Ministry of Agriculture Key Laboratory of Crop Nutrition and Fertilization, Institute of Agricultural \\ Resources and Regional Planning, Chinese Academy of Agricultural Sciences, Beijing 100081, China \\ * Correspondence: lixl@cau.edu.cn; Tel.: +86-10-6273-2574
}

Received: 25 June 2019; Accepted: 24 July 2019; Published: 29 July 2019

\begin{abstract}
Little information is known about the effects of different fertilization practices on soil microbiome in intensively managed crop rotations. The objective of this research was to investigate the response of microbial community composition (phospholipid fatty acid, PLFA) and extracellular enzyme activity to fertilization treatments through a three-year experiment. Treatments were: Control (without fertilizer, CK), chemical fertilizer (NPK), NPK + pig manure (NPKM), NPK + straw (NPKS), and NPK + both manure and straw (NPKMS). We found that fertilization had no effect on the microbial abundance except arbuscular mycorrhizal fungi (AMF) PLFA. Soil microbial community composition was significantly affected by crop species and to a lesser extent by fertilization, with a greater influence on the wheat harvest. In addition, soil enzyme activities were enhanced by fertilization, especially in wheat season. Over three years, compared with NPK treatment, addition of organic manure or straw (NPKS and NPKMS) significantly increased the activities of the enzymes except invertase and urease, and the effect was greater at wheat harvest than the maize harvest. Our results indicate that the response of soil microbial community structure and enzyme activities to fertilization takes precedence than microbial biomass in the short term. The temporal variation in soil microbial community structure and enzyme activities in the crop rotation indicate that crop species may be carefully considered for sustainable agricultural intensification management.
\end{abstract}

Keywords: manure; wheat-maize; microbial community structure; enzyme activity

\section{Introduction}

To feed the increasing population, increased grain production is critically dependent on chemical fertilizer inputs which can overcome the nutrient deficiency. However, the excessive use of chemical fertilizers may decrease nutrient use efficiency and potentially result in soil acidification [1], eutrophication [2], and greenhouse gas emissions and $\mathrm{N}$ leaching [3]. In order to ensure food security, reducing the input amount of chemical nitrogen to agricultural systems is very important. The replacement of mineral fertilizer with organic materials including manure or straw is an option that may be useful to reduce the input of chemical fertilizers used while maintaining soil quality and sustainable agricultural production [4]. Soil microorganisms are tightly involved in soil formation, nutrient mineralization, and soil organic matter turnover $[5,6]$. Thus, understanding how the microbe response to chemical and manure fertilizers or straw return is important for manure and straw management, which are contributing to sustainable agricultural intensification. 
Numerous studies found that fertilization management or crop type exert a strong influence on biomass of soil microbes and community structure $[7,8]$. For example, compared with an unfertilized control, fertilizer $\mathrm{N}$ significantly increased soil microbial biomass with an average of $15.1 \%$ based on a meta-analysis through 100 datasets from long-term trials of the world [9]. The addition of chemical $\mathrm{N}$ fertilizer generally promoted the growth of fungi [10]. By contrast, a study found that fertilizer $\mathrm{N}$ application lowered the abundance and/or diversity of soil microbes as the result of soil acidification [11]. Compared with chemical fertilizer, addition of manure significantly increased the soil bacterial diversity at maize harvest [12]. Crop type can also influence soil microbial biomass and community structure mainly through the root exudates and crop residues [13]. Most of the studies were about the fertilization effect on the microbial community over single crops. Crop rotation systems with different crop types may increase soil microbial biomass and activity [14]. However, the effect of fertilization management on microbial community in crop rotation systems is not well understood. Several studies showed that the soil microbial community differs among crop species $[15,16]$. The changes in community structure over the growing season showed a greater variability than that associated with crop management, such as fertilization, tillage, or drainage $[17,18]$. Another study found that both fertilizer regime and timing showed a significant effect on bacterial community structure in a wheat-rice cropping system [19]. Hence, it is necessary to explore the relative contribution of fertilization and timing on the changes in crop rotation associated microbial communities.

Extracellular enzymes play an important role in depolymerizing and mineralizing organic matter and are closely related to environmental quality [20]. The enzymes $\alpha-1,4$-glucosidase (AG), $\beta$-cellobiosidase (CBH), $\beta-1,4$-xylosidase (XYL), and urease control the release of biologically available carbon and $\mathrm{N}$ from organic compounds [21]. Enzyme activity is sensitive to agricultural management practices such as tillage, land use, and farming practices [22]. Compared to soils amended with mineral fertilizers, application of organic manures generally increases soil enzyme activities, which reflects a higher nutrient cycling capacity. For example, the addition of pig manure significantly increased enzyme activities, which were positively correlated with soil organic matter content in the sub-tropical region of South China after 20 years of different fertilization regimes [23]. In contrast, application of mineral fertilizers decreased the activities of $\mathrm{C}$ and $\mathrm{N}$-related hydrolytic enzymes, perhaps because enzymes are not required by microbes to acquire $C$ and $N$ nutrients [24]. Soil enzyme may be used to predict biological status and soil quality as affected by farm management practices. However, seasonal change of soil enzyme activities in response to fertilization has rarely been investigated.

In contrast to most previous researches that observed the effect of fertilization on single crop, our study focused on the microbial community dynamics over a rotation system of winter wheat-summer maize in a field. The microbial indicators (phospholipid fatty acid (PLFA) biomarkers), enzyme activities (invertase, urease AG, CBH, and XYL), and soil chemical variables were analyzed at each harvest season. We hypothesized that the soil microbial biomass and extracellular enzyme activities may be changed under different fertilization practices. The fertilization effects may be higher at wheat season than that in maize season, as wheat grow throughout the low precipitation and temperature growing season.

\section{Materials and Methods}

\subsection{Discription of the Experimental Site}

The experiment was conducted at the Quzhou Experimental Station of China Agricultural University ( $36^{\circ} 42^{\prime} \mathrm{N}, 114^{\circ} 54^{\prime} \mathrm{E}$; $40 \mathrm{~m}$ a.s.l.) in October 2010. The site was at Quzhou County, Hebei province, with the commonest agricultural systems of winter wheat-summer maize. The mean annual temperature and mean annual precipitation were $13.2^{\circ} \mathrm{C}$ and $494 \mathrm{~mm}$, respectively. The soil is Cambisol with a silt loam texture and has the basic chemical properties from one composite soil sample before the experiment as follows: Soil organic matter $13.7 \mathrm{~g} \mathrm{~kg}^{-1}$, total $\mathrm{N} 0.90 \mathrm{~g} \mathrm{~kg}^{-1}$, available P $12.0 \mathrm{mg} \mathrm{kg}^{-1}$ and exchangeable $\mathrm{K}\left(\mathrm{NH}_{4} \mathrm{OAc}-\mathrm{K}\right) 176 \mathrm{mg} \mathrm{kg}^{-1}$. 
This short time experimental site comprised of five treatments with four replicates: (1) CK control receiving no fertilizer; (2) NPK inorganic NPK, with $300 \mathrm{~kg} \mathrm{~N} \mathrm{ha}^{-1}$ for wheat (application rate of N before planting, re-greening and jointing stages was based on the ratio of 4:3:3, respectively), PK rates of 50 and $80 \mathrm{~kg} \mathrm{ha}^{-1}$ respectively. $250 \mathrm{~kg} \mathrm{~N} \mathrm{ha}^{-1}$ for maize (application rate of $\mathrm{N}$ before planting and V12 stage was based on the ratio of 2:3, respectively), and PK rates of 20 and $40 \mathrm{~kg} \mathrm{ha}^{-1}$, respectively. Urea, super-phosphate and potassium sulphate were the sources of N, P, and K; (3) NPK + manure (NPKM) 50\% NPK + manure, 50\% of fertilizer N replaced by a commercial manure with $44.2 \% \mathrm{C}, 4.4 \%$ $\mathrm{N}, 2.3 \% \mathrm{P}$, and $0.7 \% \mathrm{~K}$ [25], $6000 \mathrm{~kg} \mathrm{ha}^{-1}$ for manure; (4) NPK + straw return (NPKS) $100 \% \mathrm{NPK}+$ straw return; (5) NPKMS NPKM + straw return. The straw was returned back to the field after chopped at the crops' harvest season. The application rates of wheat straw in 2011, 2012, and 2013 were 7.9, 6.0, 6.4 $\mathrm{Mg} \mathrm{ha}^{-1}$ in NPKS and 9.0, 8.3, 6.6 $\mathrm{Mg} \mathrm{ha}^{-1}$ in NPKMS according to between-year yield variation. The application rates of maize straw in 2011 and 2012 were 5.4 and $6.8 \mathrm{Mg} \mathrm{ha}^{-1}$ in NPKS and 6.0 and 6.5 $\mathrm{Mg} \mathrm{ha}^{-1}$ in NPKMS. Each plot was $5 \times 10 \mathrm{~m}$.

\subsection{Sampling and Chemical Measurement}

One composite sample of four cores for each plot was collected at 0-20 cm soil depth between planting rows in June and October in 2011, 2012, and 2013. The fresh soil samples were passed through $3 \mathrm{~mm}$ sieve. The continuous flow analysis (TRAACS 2000) was used to analyze soil $\mathrm{N}_{\min }$ after extracted by $\mathrm{CaCl}_{2}$ solution with $0.01 \mathrm{~mol} \mathrm{~L}^{-1}$ [26]. The left soil samples were sieved $(2 \mathrm{~mm})$ and divided into two sub-samples. One portion was air-dried for analysis of soil chemical properties and the other one was stored at $-20{ }^{\circ} \mathrm{C}$ for determination of soil microbial biomass and enzymatic activities. The P concentration was analyzed colorimetrically after dried soil extracted with $0.05 \mathrm{~mol}$ $\mathrm{L}^{-1} \mathrm{NaHCO}_{3}$ for $1 \mathrm{~h}$ [27]. The method of dichromate oxidation was used to determine soil organic carbon [28]. Soil $\mathrm{pH}$ was measured in a ratio of 1:2.5 for soil/water $\left(\mathrm{H}_{2} \mathrm{O}\right)$.

\subsection{Phospholipid Fatty Acid (PLFA) Analysis}

The structure of the soil microbial community was assessed using analysis of groups of phospholipid fatty acid (PLFA) analysis according to the methods [29]. Various functional groups of microorganisms were represented by individual fatty acids [30]. Biomarkers a15:0, i15:0, i16:0,

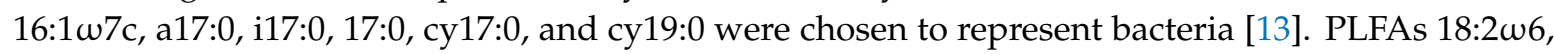
$9 c$, and $18: 1 \omega 9 c$ were chosen to represent fungal biomarkers and $16: 1 \omega 5 c$ served as a biomarker for arbuscular mycorrhizal (AM) fungi [31]. Total PLFAs is the biomarkers sum of bacteria, fungi, and mycorrhizal.

\subsection{Soil Enzyme Activities}

Soil urease activity was measured by the amount of ammonium released from soil added urea [32]. Soil invertase activity was determined by a colorimetric method [33]. The enzymes except invertase and urease were measured using MUF-linked model substrates yielding the highly fluorescent cleavage products 4-methylumbelliferyl (MUB) upon hydrolysis [34,35]. Starch is hydrolyzed by the action of $\alpha$-1,4-glucosidase (AG) to glucose. Cellulose is hydrolyzed by $\beta$-cellobiosidase (CBH) to low-molecular-weight substances (cellobiose and glucose). Xylans are major components of hemicelluloses and are hydrolyzed by the action of $\beta-1,4$-xylosidase $(X Y L)$ on the monomer xylose. The activities of AG, CBH, and XYL were determined using the substrate of 4-MUB- $\alpha$-1,4-glucosidase, 4 -MUB- $\beta$-cellobiosidase, and 4-MUB- $\beta-1,4$-xylosidase, respectively. The activities were expressed in units of $\mathrm{nmol} \mathrm{h}^{-1} \mathrm{~g}^{-1}$.

Total enzyme activity is calculated as the geometric mean of activities (GMea) of all enzymes [36] and five enzymes were included here. The geometric mean of the assayed enzyme activities was calculated as follows:

$$
\text { GMea }=\sqrt[5]{\text { Urease } \times \text { Invertase } \times \mathrm{AG} \times \mathrm{CBH} \times \mathrm{XYL}}
$$


where AG, CBH, and XYL represent $\alpha-1,4$-glucosidase, $\beta$-cellobiosidase, $\beta-1,4$-xylosidase.

\subsection{Statistical Analysis}

All data are presented as mean \pm SEM. All the data were tested for homogeneity of variance and log-transformed to achieve normality of distribution before conducting analysis of variance (ANOVA). One-way ANOVA was performed using the SPSS 18.0 for Windows software package to test the effects of treatments on soil chemical properties, contents of phospholipid fatty acids, and enzyme activities with the $5 \%$ level of the least significant difference (LSD) test. Analyses across time were performed using repeated measures ANOVA to test for multivariate significance using Treatment, Year (2011, 2012, and 2013), and Crop species. Redundancy analysis (RDA) was conducted using CANOCO 4.5 [37] to explore the relationships among the response variables.

\section{Results}

\subsection{Soil Chemical Properties}

Compared with CK, fertilization had no effect on the three year-average content of soil chemical properties except AP with increase of $160.3 \%$ and $103.5 \%$ under NPKMS for wheat and maize, respectively (Figure 1). Furthermore, there were no significant differences among fertilization treatments for the three-year average of each soil properties. An increase in soil $\mathrm{N}_{\min }$ content was observed starting from the first year. Application of manure (NPKM and NPKMS) increased soil available $P$ and the effect was more pronounced in 2012 and 2013. The soil organic matter (SOM) contents did not differ significantly among different treatments but tended to be highest in the NPKMS treatment and the increase of $17.8 \%$ and $14.3 \%$ were significant at wheat and maize harvest in 2013. Application of chemical fertilizer (NPK) significantly decreased the soil $\mathrm{pH}$ compared with the control at wheat season in 2011 and maize season in 2013 but organic fertilization had no significant influence on soil $\mathrm{pH}$ value.

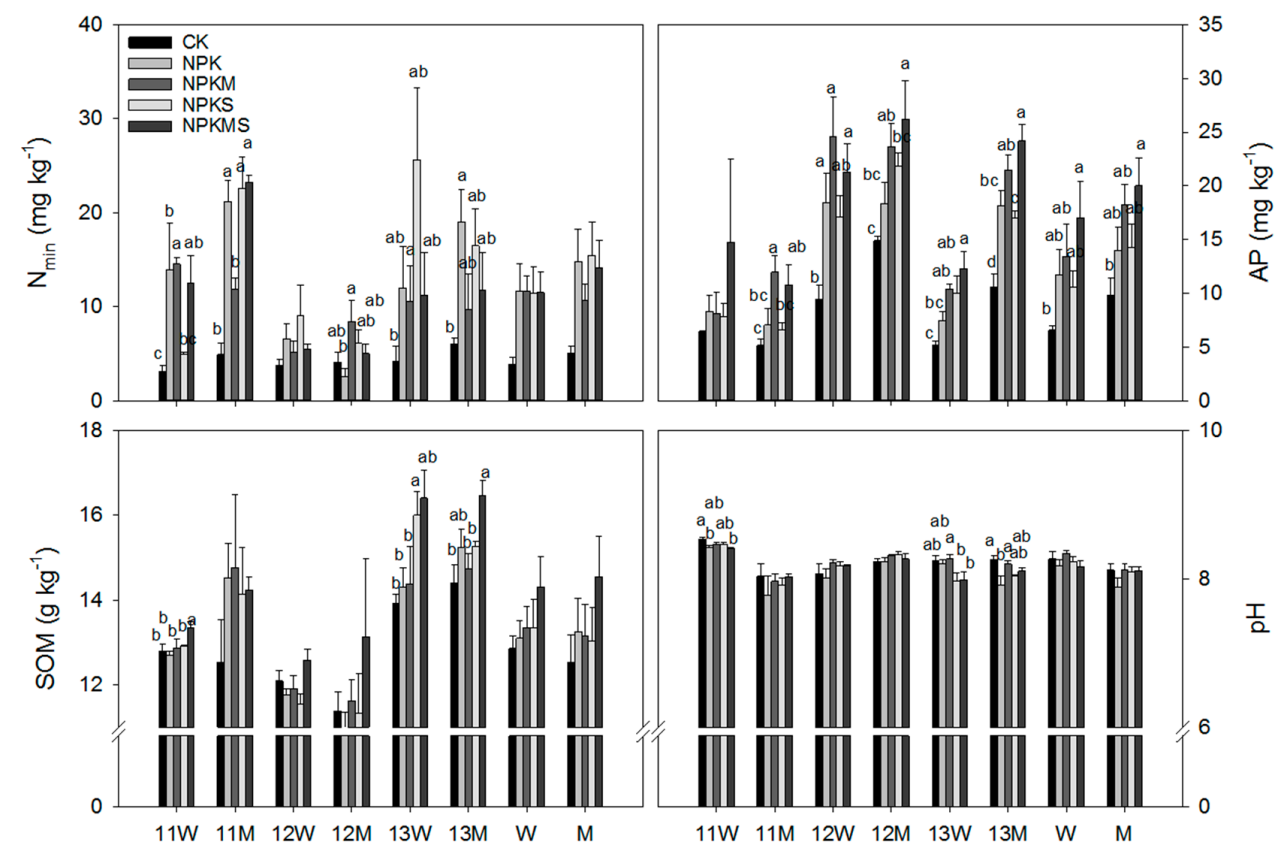

Figure 1. Effect of different fertilizer treatments on soil $\mathrm{N}_{\min }, \mathrm{AP}, \mathrm{SOM}$, and $\mathrm{pH}$ over three years. Data are means $\pm \operatorname{SEM}(n=3)$. Significant differences among treatments $(p<0.05)$ are indicated by different letters. CK, control receiving no fertilizer; NPK, 100\% NPK; NPKM, manure + 50\% NPK; NPKS, NPK + crop straw; NPKMS, NPKM + crop straw; F/B ratio, ratio of fungi to bacteria; $\mathrm{N}_{\min }$, mineral nitrogen; $\mathrm{AP}$, available phosphorus; $\mathrm{SOM}$, soil organic matter; $\mathrm{W}$ and $\mathrm{M}$ represented the wheat and maize harvest season, respectively; 11, 2011; 12, 2012; 13, 2013. 


\subsection{Microbial Biomass and Community Structure}

Fertilization had no effect on the three year-average contents of phospholipid fatty acids except arbuscular mycorrhizal fungi (AMF) in the wheat season (Figure 2). Compared with CK, fertilization showed no effect on the content of total PLFAs, bacteria, fungi, and AMF PLFAs compared with the control over three years apart from the wheat season of 2013 in which the content of soil AMF PLFAs increased significantly in NPKM, NPKS, and NPKMS. In the wheat season of 2012 the application of manure (NPKM) showed a significantly lower content of bacterial PLFAs and higher ratio of fungi to bacteria (F/B ratio) compared to NPK. The content of five microbial groups under application of straw and straw plus manure (NPKS and NPKMS) was equal to or significantly higher than NPKM. Straw addition in combination with manure (NPKMS) increased the content of total PLFAs and bacterial and AMF PLFAs compared to NPK and NPKM in the maize season of 2013. Repeated measures analysis of variation for microbial biomass using Treatment, Year (2011, 2012, and 2013), and Crop species showed that the effects of treatment and crop species were highly significant (Table 1).

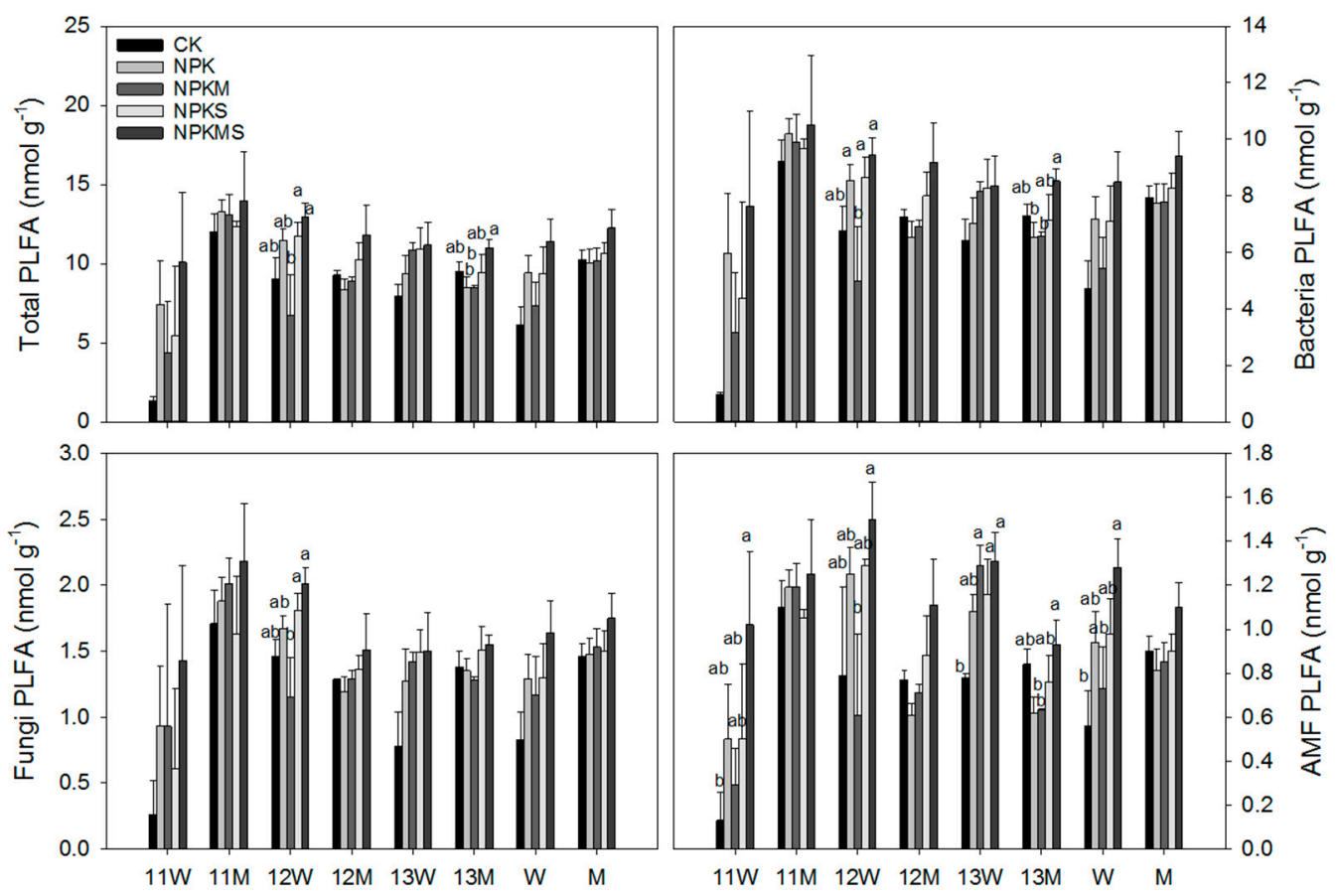

Figure 2. Phospholipid fatty acids (PLFA) at 0-20 cm depth under different fertilization treatments over three years. Data are means $\pm \operatorname{SEM}(n=3)$. Significant differences among treatments $(p<0.05)$ are indicated by different letters. CK, control receiving no fertilizer; NPK, 100\% NPK; NPKM, manure + 50\% NPK; NPKS, NPK + crop straw; NPKMS, NPKM + crop straw; W and M represented the wheat and maize harvest season, respectively; 11, 2011; 12, 2012; 13, 2013; AMF, arbuscular mycorrhizal fungi.

Table 1. Repeated measures analysis of variation for microbial community and enzyme activities using Treatment, Year (2011, 2012, and 2013), and Crop species (wheat/maize).

\begin{tabular}{|c|c|c|c|c|c|c|c|c|c|c|}
\hline $\begin{array}{l}\text { Source of } \\
\text { Variation }\end{array}$ & Total PLFA & Bacteria & Fungi & AMF & Invertase & Urease & AG & $\mathrm{CBH}$ & XYL & GMea \\
\hline Treatment (T) & $3.7 *$ & $3.5 *$ & 2.2 & $4.0 * *$ & 2.1 & 1.4 & $7.4^{* * *}$ & $8.7 * * *$ & $10.8^{* * *}$ & $7.3^{* * *}$ \\
\hline Year $(\mathrm{Y})$ & 0.7 & 0.3 & 0.4 & $15.5^{* * *}$ & $9.8^{* * *}$ & $29.0^{* * *}$ & $17.3^{* * *}$ & $5.5 * *$ & $6.3^{* *}$ & $24.9 * * *$ \\
\hline Crop species (C) & $11.0^{* *}$ & $11.3^{* *}$ & $6.2 *$ & $6.7 *$ & 1.5 & 0.3 & $61.5^{* * *}$ & $65.5^{* * *}$ & $71.9^{* * *}$ & $34.0 * * *$ \\
\hline $\mathrm{T} \times \mathrm{Y}$ & 0.6 & 0.7 & 0.6 & 1.9 & 0.8 & 0.7 & 1.7 & $2.7 *$ & $2.5 *$ & $2.5^{*}$ \\
\hline $\mathrm{T} \times \mathrm{C}$ & 1.0 & 1.0 & 0.6 & 1.5 & 0.6 & 1.2 & 1.8 & 1.8 & 1.7 & 1.0 \\
\hline
\end{tabular}

* Data represent $F$ values. PLFA, phospholipids fatty acids; AMF, arbuscular mycorrhizal fungi; AG, $\alpha-1,4$-glucosidase; $\mathrm{CBH}, \beta$-cellobiosidase; XYL, $\beta-1,4$-xylosidase; GMea, the geometric mean of the assayed enzyme activities; ${ }^{*} p<0.05$; ** $p<0.01 ; * * * p<0.001$. 


\subsection{Soil Enzyme Activities}

Repeated measures analysis of variation for soil enzyme activities showed that soil enzyme activities were significantly affected by year, treatment and crop species (Table 1). In the 2011 wheat harvest season, all five enzymes and GMea showed no significant difference among treatments except urease (Figure 3). NPK showed the highest activity of invertase in 2011 maize harvest season. Furthermore, compared with CK, NPKMS significantly increased activities of AG and CBH. In 2012, compared to $\mathrm{CK}$, fertilization had no effect on invertase, $\mathrm{CBH}$, and GMea at wheat and maize harvest, and shows the higher activities of AG and XYL at the wheat harvest. However, there were no significant differences among the fertilization treatments. The effect of fertilization was more pronounced in 2013. In general, the enzyme activities $(\mathrm{AG}, \mathrm{CBH}$, and $\mathrm{XYL}$ ) were much higher in the organic treatments than in the control and NPK treatments. Addition of straw significantly increased the contents of AG and $\mathrm{XYL}$, and the enzymatic activities of $\mathrm{CBH}, \mathrm{XYL}$, and NAG in NPKMS had the highest values. The activity of urease was variable and did not differ significantly among treatments except for a slight increase in the NPKM treatment in 2013. The activities of AG, CBH, XYL, and GMea showed strong seasonal variability with greater activity at the wheat harvest relative to the maize harvest.

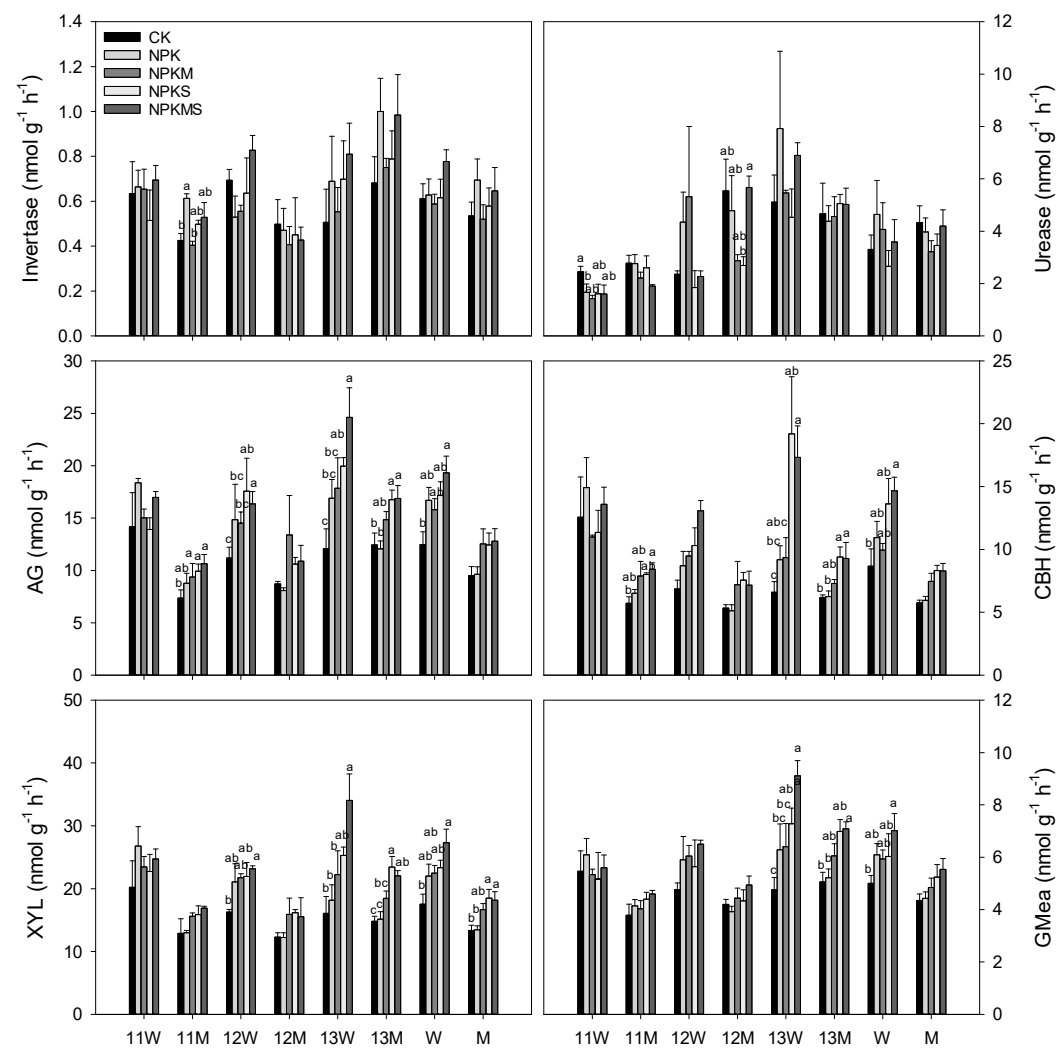

Figure 3. Soil enzyme activities at $0-20 \mathrm{~cm}$ depth under different fertilization treatments over three years. Data are means $\pm \operatorname{SEM}(n=3)$. Significant differences among treatments $(p<0.05)$ are indicated by different letters. CK, control receiving no fertilizer; NPK, 100\% NPK; NPKM, manure + 50\% NPK; NPKS, NPK + crop straw; NPKMS, NPKM + crop straw; $W$ and M represented the wheat and maize harvest season, respectively; 11, 2011; 12, 2012; 13, 2013; AG, $\alpha$-1,4-glucosidase; $C B H, ~ \beta$-cellobiosidase; XYL, $\beta-1,4$-xylosidase; GMea, the geometric mean of the assayed enzyme activities.

\section{Discussion}

Sustainable agro-ecosystem relies upon an adequate amount of SOM [38]. Good cropping techniques such as the addition of manure and straw may exerts benefits on soil carbon sequestration $[39,40]$. Fertilization treatments showed the positive effect on SOM in the third year and treatment of NPKMS showed the highest value (Figure 1). Our results indicate that manure application 
has the potential to increase SOM in a relatively short time frame. Previous studies indicate that SOM content was not improved by the two-year crop successions [41]. Moreover, manure application and crop residues efficiently increase the SOC content by 0.26 and $0.18 \mathrm{Mg} \mathrm{C} \mathrm{ha}^{-1}$ year ${ }^{-1}$, but the SOC stock did not change in the control and $\mathrm{N}$ fertilized plots during a maize-wheat rotation practiced for 28 years [42]. Hence, manure application in combination with straw has been proposed to be the best management option in terms of increasing soil fertility.

The effect of fertilization treatments on soil microbial biomass and community was minimal. Contrary to previous studies on farmland $[43,44]$, we found no significant effects of fertilization microbial biomass except arbuscular mycorrhizal fungi (AMF). Compared with chemical fertilizer, manure amendment significantly increased AMF [45]. Some previous studies indicated that fertilization decreased AMF [46,47], while other studies indicated no clear changes $[48,49]$. The important reason for the increase of AMF under manure amendment could be that the preference of AMF favor a near neutral or alkaline soil $\mathrm{pH}[50,51]$. The microbial community composition was dominated by bacteria, and bacteria can react more rapidly to environmental change than fungi with a shorter turnover time [52]. The response of the microbial community to agricultural practices was minimal [53]. It may be because three years of fertilization application may be short and had no impacts on the whole soil microbial community. According to the redundancy analysis, the biomass of the soil microbial community components was positively correlated with the correlated with SOM for both wheat and maize. This observation confirms that for a given site, changes in microbial community composition may be driven by fertilizer induces changes in SOM [54], with a slight change in our present study.

In the present study, the soil microbial community was significantly affected by crop species (C) and treatment $(\mathrm{T})$ rather than year $(\mathrm{Y})$ (Table 1). This agrees with other studies where crop species showed an effect on microbial characters $[17,55]$. The response of the soil microbial community depends on various factors including crop species [56] and the duration. There was a time delay in the change of community after carbon addition [57], with the average duration of $4.9 \pm 12.6$ years [58]. The effect of a high level manure addition of $5 \%$ on a mass basis persisted longer than that of a low dose application of $0.5 \%$ on a mass basis [59]. In our study, microbial communities are mainly affected by crop types rather than fertilization, which may be related to a shorter fertilization time. Hence, long-term monitoring of the microbial community in response to fertilization in rotation systems is necessary for the development of optimum fertilization strategies.

Soil microbes regulate extracellular enzyme production to decompose SOM and recycle nutrients in the soil. The soil enzyme activities have been regarded as potential indicators of soil fertility [60]. In intensively managed agriculture soils microbial metabolic activity tends to a more rapid change in response to management practices than community structure [61], which was consistent with our hypothesis. The soil enzyme activities were significantly affected by crop species and year and to a lesser extent by treatment (Table 1). The effect of year on soil enzyme activities may correlate with the temporal change of soil temperature, moisture, and the oxygen gradient [18]. The climatic variables such as precipitation [62] and air temperature may influence the enzyme activities. The higher enzyme activities (AG, $\mathrm{CBH}$, and $\mathrm{XYL}$ ) at the wheat harvest compared to the maize harvest imply that maize residues and the lower temperatures throughout the wheat season may be more conducive to carbon sequestration. Maize straw is high in plant derived $C$ such as cellulose and hemicelluloses which may stimulate fungal growth [57] and activity during the wheat season. As straw return is highly correlated with climatic factors, manure addition in combination with straw may be the optimum fertilization strategy for increasing SOM in this region [39]. An experiment conducted for 30 years indicated that organic manure $\left(75 \mathrm{Mg} \mathrm{ha}^{-1}\right)$ application increased soil $\beta$-glucosidase activity significantly compared with chemical fertilizer at wheat harvest [63]. Another study found that long-term manure application significantly increased activities of soil invertase $108 \%$ and soil urease $136 \%$ [64]. The increased activities of these $\mathrm{C}$-cycling enzymes likely reflected higher turnover rates of soil $\mathrm{C}$ and this may be important for the accumulation of SOM [65]. 


\section{Conclusions}

The relatively short fertilization experiment results showed that the fertilization had impact on soil microbial community structure and soil enzyme activities rather than microbial biomass. AMF is more sensitive to fertilization than the other microorganisms, and is mainly expressed in the wheat season. The trend of increasing soil OM (not always significant) and activities enzymes related with $\mathrm{C}$-cycling in the manure and straw return treatments indicate that carbon limitation may be offset by adding diverse carbon sources to the soil. There is greater potential to enhance carbon sequestration in the wheat than in maize. Furthermore, the fertilization effect may be greater in wheat harvest season than that in maize. It is important to consider the microbial community and enzyme activities with crop species for the future sustainable fertilization management.

Author Contributions: Y.Z. and J.Z. conceived and designed the experiments; Y.Z., T.L., and S.B. executed the experiments and measured the data; Y.Z. analyzed the data and wrote the paper; Y.Z., H.W., J.Z., and X.L. revised the manuscript.

Funding: This research was funded by the Postdoctoral Science Foundation of China (2017M620965), the Inter-Governmental International Science and Technology Innovation Cooperation (S2016G0053), the National Basic Research Program of China (2015CB150500), and the Chinese Ministry of Agriculture (201103004).

Acknowledgments: In this section you can acknowledge any support given which is not covered by the author contribution or funding sections. This may include administrative and technical support, or donations in kind (e.g., materials used for experiments).

Conflicts of Interest: The authors declare no conflict of interest.

\section{References}

1. Guo, J.H.; Liu, X.J.; Zhang, Y.; Shen, J.L.; Han, W.X.; Zhang, W.F.; Christie, P.; Goulding, K.W.T.; Vitousek, P.M.; Zhang, F.S. Significant acidification in major Chinese croplands. Science 2010, 327, 1008-1010. [CrossRef]

2. Zhang, F.S.; Cui, Z.L.; Fan, M.S.; Zhang, W.F.; Chen, X.P.; Jiang, R.F. Integrated soil-crop system management: Reducing environmental risk while increasing crop productivity and improving nutrient use efficiency in China. J. Environ. Qual. 2011, 40, 1051-1057. [CrossRef]

3. Li, Y.; Liu, H.J.; Huang, G.H.; Zhang, R.H.; Yang, H.Y. Nitrate nitrogen accumulation and leaching pattern at a winter wheat: Summer maize cropping field in the North China Plain. Environ. Earth Sci. 2016, 75, 118. [CrossRef]

4. Gattinger, A.; Muller, A.; Haeni, M.; Skinner, C.; Fliessbach, A.; Buchman, N.; Mäder, P.; Stolze, M.; Smith, P.; Scialabba, N.E.H.; et al. Enhanced top soil carbon stocks under organic farming. Pro. Natl. Acad. Sci. USA 2012, 109, 18226-18231. [CrossRef]

5. Schimel, D.S. Terrestrial ecosystems and the carbon cycle. Glob. Chang. Boil. 1995, 1, 77-91. [CrossRef]

6. Doran, J.W.; Zeiss, M.R. Soil health and sustainability: Managing the biotic component of soil quality. Appl. Soil Ecol. 2000, 15, 3-11. [CrossRef]

7. Hartmann, M.; Frey, B.; Mayer, J.; Mader, P.; Widmer, F. Distinct soil microbial diversity under long-term organic and conventional farming. ISME J. 2015, 9, 1177-1194. [CrossRef]

8. Zhou, J.; Jiang, X.; Zhou, B.; Zhao, B.; Ma, M.; Guan, D.; Li, J.; Chen, S.; Cao, F.; Shen, D.; et al. Thirty four years of nitrogen fertilization decreases fungal diversity and alters fungal community composition in black soil in northeast China. Soil Biol. Biochem. 2016, 95, 135-143. [CrossRef]

9. Geisseler, D.; Scow, K.M. Long-term effects of mineral fertilizers on soil microorganisms-A review. Soil Biol. Biochem. 2014, 75, 54-63. [CrossRef]

10. Esperschütz, J.; Gattinger, A.; Mäder, P.; Schloter, M.; Fließbach, A. Response of soil microbial biomass and community structures to conventional and organic farming systems under identical crop rotations. FEMS Microbiol. Ecol. 2007, 61, 26-37. [CrossRef]

11. He, J.Z.; Shen, J.P.; Zhang, L.M.; Zhu, Y.G.; Zheng, Y.M.; Xu, M.G.; Di, H.J. Quantitative analyses of the abundance and composition of ammonia-oxidizing bacteria and ammonia-oxidizing archaea of a Chinese upland red soil under long-term fertilization practices. Environ. Microbiol. 2007, 9, 2364-2374. [CrossRef]

12. Li, J.J.; Zhou, X.M.; Yan, J.X.; Li, H.J.; He, J.Z. Effects of regenerating vegetation on soil enzyme activity and microbial structure in reclaimed soils on a surface coal mine site. Appl. Soil Ecol. 2015, 87, 56-62. [CrossRef] 
13. Moore-Kucera, J.; Dick, R.P. PLFA profiling of microbial community structure and seasonal shifts in soils of a Douglas-fir chronosequence. Microb. Ecol. 2008, 55, 500-511. [CrossRef]

14. Balota, E.L.; Colozzi-Filho, A.; Andrade, D.S.; Dick, R.P. Microbial biomass in soils under different tillage and crop rotation systems. Biol. Fertil. Soils 2003, 38, 15-20. [CrossRef]

15. Ofek-Lalzar, M.; Sela, N.; Goldman-Voronov, M.; Green, S.J.; Hadar, Y.; Minz, D. Niche and host-associated functional signatures of the root surface microbiome. Nat. Commun. 2014, 5, 4950. [CrossRef]

16. Reinhold-Hurek, B.; Bunger, W.; Burbano, C.S.; Sabale, M.; Hurek, T. Roots shaping their microbiome: Global hotspots for microbial activity. Annu. Rev. Phytopathol. 2015, 53, 403-424. [CrossRef]

17. Bardgett, R.D.; Lovell, R.D.; Hobbs, P.J.; Jarvis, S.C. Seasonal changes in soil microbial communities along a fertility gradient of temperate grasslands. Soil Biol. Biochem. 1999, 31, 1021-1030. [CrossRef]

18. Spedding, T.A.; Hamel, S.C.; Mehuys, G.R.; Madramootoo, C.A. Soil microbial dynamics in maize-growing soil under different tillage and residue management systems. Soil Biol. Biochem. 2004, 36, 499-512. [CrossRef]

19. Zhao, J.; Ni, T.; Li, J.; Lu, Q.; Fang, Z.; Huang, Q.; Zhang, R.; Li, R.; Shen, B.; Shen, Q. Effects of organic-inorganic compound fertilizer with reduced chemical fertilizer application on crop yields, soil biological activity and bacterial community structure in a rice-wheat cropping system. Appl. Soil Ecol. 2016, 99, 1-12. [CrossRef]

20. Jian, S.; Li, J.W.; Chen, J.; Wang, G.S.; Mayes, M.A.; Dzantor, K.E.; Hui, D.F.; Luo, Y.Q. Soil extracellular enzyme activities, soil carbon and nitrogen storage under nitrogen fertilization: A meta-analysis. Soil Biol. Biochem. 2016, 101, 32-43. [CrossRef]

21. Boot, C.M.; Hall, E.K.; Denef, K.; Baron, J.S. Long-term reactive nitrogen loading alters soil carbon and microbial community properties in a subalpine forest ecosystem. Soil Biol. Biochem. 2016, 92, 211-220. [CrossRef]

22. Fan, F.; Li, Z.; Wakelin, S.A.; Yu, W.; Liang, Y. Mineral fertilizer alters cellulolytic community structure and suppresses soil cellobiohydrolase activity in a long-term fertilization experiment. Soil Biol. Biochem. 2012, 55, 70-77. [CrossRef]

23. Zhang, X.Y.; Dong, W.Y.; Dai, X.Q.; Schaeffer, S.; Yang, F.T.; Radosevich, M.; Xu, L.L.; Liu, X.Y.; Sun, X.M. Responses of absolute and specific soil enzyme activities to long term additions of organic and mineral fertilizer. Sci. Total Environ. 2015, 536, 59-67. [CrossRef]

24. DeForest, J.L.; Smemo, K.A.; Burke, D.J.; Elliott, H.L.; Becker, J.C. Soil microbial responses to elevated phosphorus and $\mathrm{pH}$ in acidic temperate deciduous forests. Biogeochemistry 2012, 109, 189-202. [CrossRef]

25. Ling, N.; Xue, C.; Huang, Q.W.; Yang, X.M.; Xu, Y.C.; Shen, Q.R. Development of a mode of application of bioorganic fertilizer for improving the biocontrol efficacy to Fusarium wilt. Biocontrol 2010, 55, 673-683. [CrossRef]

26. Peng, Y.F.; Yu, P.; Li, X.X.; Li, C.J. Determination of the critical soil mineral nitrogen concentration for maximizing maize grain yield. Plant Soil 2013, 372, 41-51. [CrossRef]

27. Murphy, J.; Riley, J. A modified single solution method for the determination of phosphate in natural waters. Anal. Chim. Acta 1962, 27, 31-36. [CrossRef]

28. Nelson, D.W.; Sommers, L. Total carbon, organic carbon, and organic matter. In Chemical and Microbiological Properties, 2nd ed.; American Society of Agronomy: Madison, WI, USA, 1982; pp. 39-579.

29. Frostegård, Å.; Bååth, E. The use of phospholipid fatty acid analysis to estimate bacterial and fungal biomass in soil. Biol. Fertil. Soils 1996, 22, 59-65. [CrossRef]

30. Zelles, L.; Bai, Q.Y.; Rackwitz, R.; Chadwick, D.; Beese, F. Determination of phospholipid-and lipopolysaccharide-derived fatty acids as an estimate of microbial biomass and community structures in soils. Biol. Fertil. Soils 1995, 19, 115-123. [CrossRef]

31. Olsson, P.A. Signature fatty acids provide tools for determination of the distribution and interactions of mycorrhizal fungi in soil. FEMS Microb. Ecol. 1999, 29, 303-310. [CrossRef]

32. Kandeler, E.; Gerber, H. Short-term assay of soil urease activity using colorimetric determination of ammonium. Biol. Fertil. Soils 1988, 6, 68-72. [CrossRef]

33. Gopal, M.; Gupta, A.; Arunachalam, V.; Magu, S.P. Impact of azadirachtin, an insecticidal allelochemical from neem on soil microflora, enzyme and respiratory activities. Bioresour. Technol. 2007, 98, 3154-3158. [CrossRef]

34. Marx, M.C.; Wood, M.; Jarvis, S.C. A microplate fluorimetric assay for the study of enzyme diversity in soils. Soil Biol. Biochem. 2001, 33, 1633-1640. [CrossRef] 
35. Saiya-Cork, K.R.; Sinsabaugh, R.L.; Zak, D.R. The effects of long term nitrogen deposition on extracellular enzyme activity in an Acer saccharum forest soil. Soil Biol. Biochem. 2002, 34, 1309-1315. [CrossRef]

36. García-Ruiz, R.; Ochoa, V.; Hinojosa, M.B.; Carreira, J.A. Suitability of enzyme activities for the monitoring of soil quality improvement in organic agricultural systems. Soil Biol. Biochem. 2008, 40, 2137-2145. [CrossRef]

37. Lepš, J.; Šmilauer, P. Multivariate Analysis of Ecological Data Using CANOCO; Cambridge University Press: Cambridge, UK, 2003.

38. Paustian, K.A.O.J.H.; Andrén, O.; Janzen, H.H.; Lal, R.; Smith, P.; Tian, G.; Tiessen, H.; Van, N.M.; Woomer, P.L. Agricultural soils as a sink to mitigate $\mathrm{CO}_{2}$ emissions. Soil Use Manag. 1997, 13, 230-244. [CrossRef]

39. Liang, B.; Yang, X.Y.; He, X.H.; Zhou, J.B. Effects of 17 years fertilization on soil microbial biomass C and $\mathrm{N}$ and soluble organic $\mathrm{C}$ and $\mathrm{N}$ in loessial soil during maize growth. Biol. Fertil. Soils 2011, 47, 121-128. [CrossRef]

40. Subehia, S.K.; Sepehya, S.; Rana, S.S.; Negi, S.C.; Sharma, S.K. Long-term effect of organic and inorganic fertilizers on rice (Oryza sativa L.)-wheat (Triticum aestivum L.) yield, and chemical properties of an acidic soil in the western Himalayas. Exp. Agric. 2013, 49, 382-394. [CrossRef]

41. Triberti, L.; Nastri, A.; Giordani, G.; Comellini, F.; Baldoni, G.; Toderi, G. Can mineral and organic fertilization help sequestrate carbon dioxide in cropland? Eur. J. Agron. 2008, 29, 13-20. [CrossRef]

42. Singh Brar, B.; Singh, J.; Singh, G.; Kaur, G. Effects of long term application of inorganic and organic fertilizers on soil organic carbon and physical properties in maize-wheat rotation. Agronomy 2015, 5, 220-238. [CrossRef]

43. Williams, A.; Borjesso, G.; Hedlund, K. The effects of 55 years of different inorganic fertilizer regimes on soil properties and microbial community composition. Soil Biol. Biochem. 2013, 67, 41-46. [CrossRef]

44. Bowles, T.M.; Acosta-Martínez, V.; Calderón, F.; Jackson, L.E. Soil enzyme activities, microbial communities, and carbon and nitrogen availability in organic agroecosystems across an intensively-managed agricultural landscape. Soil Biol. Biochem. 2014, 68, 252-262. [CrossRef]

45. Qin, H.; Lu, K.; Strong, P.J.; Xu, Q.; Wu, Q.; Xu, Z.; Wu, Q.F.; Xu, Z.X.; Xu, J.; Wang, H. Long-term fertilizer application effects on the soil, root arbuscular mycorrhizal fungi and community composition in rotation agriculture. Appl. Soil Ecol. 2015, 89, 35-43. [CrossRef]

46. Bhadalung, N.N.; Suwanarit, A.; Dell, B.; Nopamornbodi, O.; Thamchaipenet, A.; Rungchuang, J. Effects of long-term NP-fertilization on abundance and diversity of arbuscular mycorrhizal fungi under a maize cropping system. Plant Soil 2005, 270, 371-382. [CrossRef]

47. Lin, X.; Feng, Y.; Zhang, H.; Chen, R.; Wang, J.; Zhang, J.; Chu, H. Long-term balanced fertilization decreases arbuscular mycorrhizal fungal diversity in an arable soil in North China revealed by 454 pyrosequencing. Environ. Sci. Technol. 2012, 46, 5764-5771. [CrossRef]

48. Corkidi, L.; Rowland, D.L.; Johnson, N.C.; Allen, E.B. Nitrogen fertilization alters the functioning of arbuscular mycorrhizas at two semiarid grasslands. Plant Soil 2002, 40, 299-310. [CrossRef]

49. Chen, Y.L.; Zhang, X.; Ye, J.S.; Han, H.Y.; Wan, S.Q.; Chen, B.D. Six-year fertilization modifies the biodiversity of arbuscular mycorrhizal fungi in a temperate steppe in Inner Mongolia. Soil Biol. Biochem. 2014, 69, 371-381. [CrossRef]

50. Toljander, J.F.; Santos-González, J.C.; Tehler, A.; Finlay, R.D. Community analysis of arbuscular mycorrhizal fungi and bacteria in the maize mycorrhizosphere in a long-term fertilization trial. FEMS Microb. Ecol. 2008, 65, 323-338. [CrossRef]

51. Helgason, T.; Fitter, A.H. Natural selection and the evolutionary ecology of the arbuscular mycorrhizal fungi (Phylum Glomeromycota). J. Exp. Bot. 2009, 60, 2465-2480. [CrossRef]

52. Bardgett, R. The Biology of Soil: A Community and Ecosystem Approach; Oxford University Press: Oxford, UK, 2005.

53. Lauber, C.L.; Ramirez, K.S.; Aanderud, Z.; Lennon, J.; Fierer, N. Temporal variability in soil microbial communities across land-use types. ISME J. 2013, 7, 1641. [CrossRef]

54. Bei, S.; Zhang, Y.; Li, T.; Christie, P.; Li, X.; Zhang, J. Response of the soil microbial community to different fertilizer inputs in a wheat-maize rotation on a calcareous soil. Agric. Ecosys. Environ. 2018, 260, 58-69. [CrossRef]

55. Shi, P.; Wang, S.P.; Jia, S.G.; Gao, Q. Effect of 25-year fertilization on soil microbial biomass and community structure in a continuous corn cropping system. Arch. Agron. Soil Sci. 2015, 61, 1303-1317. [CrossRef] 
56. Smith, A.P.; Marín-Spiotta, E.; Balser, T. Successional and seasonal variations in soil and litter microbial community structure and function during tropical post agricultural forest regeneration: A multiyear study. Glob. Chang. Boil. 2015, 21, 3532-3547. [CrossRef]

57. Reardon, C.L.; Wuest, S.B. Soil amendments yield persisting effects on the microbial communities-a 7-year study. Appl. Soil Ecol. 2016, 101, 107-116. [CrossRef]

58. Allison, S.D.; Martiny, J.B.H. Resistance, resilience, and redundancy in microbial communities. Pro. Natl. Acad. Sci. USA 2008, 105, 1512-11519. [CrossRef]

59. Saison, C.; Degrange, V.; Oliver, R.; Millard, P.; Commeaux, C.; Montange, D.; Roux, X.L. Alteration and resilience of the soil microbial community following compost amendment: Effects of compost level and compost-borne microbial community. Environ. Microbiol. 2006, 8, 247-257. [CrossRef]

60. Schloter, M.; Dilly, O.; Munch, J.K. Indicators for evaluating soil quality. Agric. Ecosyst. Environ. 2003, 98, 255-262. [CrossRef]

61. Burger, M.; Jackson, L.E. Microbial immobilization of ammonium and nitrate in relation to ammonification and nitrification rates in organic and conventional cropping systems. Soil Biol. Biochem. 2003, 35, $29-36$. [CrossRef]

62. McSherry, M.E.; Rithcie, M.E. Effects of grazing on grassland soil carbon: A global review. Glob. Chang. Boil. 2013, 19, 1347-1357. [CrossRef]

63. Liu, E.; Yan, C.R.; Mei, X.R.; He, W.Q.; Bing, S.H.; Ding, L.P.; Liu, Q.; Liu, S.; Fan, T.L. Long-term effect of chemical fertilizer, straw, and manure on soil chemical and biological properties in northwest China. Geoderma 2010, 158, 173-180. [CrossRef]

64. Ge, G.F.; Li, Z.F.; Fan, F.L.; Chu, G.X.; Hou, Z.N.; Liang, Y.C. Soil biological activity and their seasonal variations in response to long-term application of organic and inorganic fertilizers. Plant Soil 2010, 326, 31-44. [CrossRef]

65. Saha, S.; Prakash, V.; Kundu, S.; Kumar, N.; Mina, B.L. Soil enzymatic activity as affected by long term application of farm yard manure and mineral fertilizer under a rainfed soybean-wheat system in NW Himalaya. Eur. J. Soil Biol. 2008, 44, 309-315. [CrossRef]

(C) 2019 by the authors. Licensee MDPI, Basel, Switzerland. This article is an open access article distributed under the terms and conditions of the Creative Commons Attribution (CC BY) license (http://creativecommons.org/licenses/by/4.0/). 